\title{
Turning the Pork Industry \\ Upside Down: \\ Storm Lake's Hygrade Work Force and the Impact of the 1981 Plant Closure
}

\author{
MARK A. GREY
}

WHEN STORM LAKE'S HYGRADE Food Products porkpacking plant closed on October 24, 1981, some six hundred workers lost their jobs, and the community lost its largest and best-paying employer. The plant's closure was not an isolated event. Several Iowa meatpacking plants closed in the wake of a major restructuring of the industry. ${ }^{1}$ But the Hygrade plant is particularly significant because it subsequently became the first major pork facility to be purchased by IBP, Inc. There IBP

The research for this article was made possible by a Summer Research Fellowship from the Graduate College of the University of Northern Iowa. Thanks to Timothy Fox for his research assistance. Professors Carol Weisenberger, Robert Neymeyer, and Bruce Fehn provided helpful suggestions and encouragement. I also wish to express my sincere appreciation to those former $\mathrm{Hy}$ grade workers and other members of the Storm Lake community who were interviewed and submitted photos and other materials for the preparation of this article and to Mark Smith, secretary-treasurer of the Iowa Federation of Labor, AFL-CIO, who granted me access to interviews with Storm Lake workers in the Iowa Labor History Oral Project.

1. In 1981 and 1982, five large pork plants shut down in Iowa, and two other plants ceased hog slaughter operations, eliminating 4,500 to 5,500 jobs. An additional 2,500 jobs were lost in beef packing. By 1982, Iowa had lost one-third of its meatpacking jobs since 1975. Mickey Lauria and Peter S. Fisher, Plant Closings in Iowa: Causes, Consequences, and Legislative Options (Iowa City, 1983).

THE ANNALS OF IOWA 54 (Summer 1995). CThe State Historical Society of Iowa, 1995. 
began - as one Hygrade worker put it - to "turn the pork industry upside down."

The following historical account of the years leading up to Hygrade's closure and its purchase and reopening by IBP relies heavily on the voices of former Hygrade workers. Although $\mathrm{Hy}-$ grade's closing was documented in the press and in reports to policy-making institutions, it is important to add to the historical record the recollections and perspectives of these workers, who were in many ways the most important casualties of the transformation of the pork industry.

The transition from Hygrade to IBP had tremendous consequences for Storm Lake's work force. As they described themselves, Hygrade workers represented a stable, local work force that enjoyed high wages and strong union representation. In many ways, they embodied the "old" Storm Lake, with its white population of European descent, working-class values, and a satisfaction with rural life that encouraged deep roots in the community. By contrast, IBP - one of the so-called new breed meatpackers - drove down wages and benefits, increased productivity, neutralized unions, experienced high employee turnover, and relied increasingly on immigrant and refugee labor. When IBP opened in 1982, very few Hygrade workers were hired, and new workers increasingly came from the global labor market that looked less and less like the local population. High turnover in the plant meant that many newcomers did not settle in the community.

This change in Storm Lake's work force took place against a historical backdrop that includes the community's longtime relationship with pork packing, four years of negotiations among labor, management, and city officials leading up to the closure of the Hygrade plant, IBP's eventual purchase of the plant in 1982, and many Hygrade workers' hopes for employment with the new owners of the plant. When those hopes were dashed, the significance of the transformation in the pork packing industry became clear to Storm Lake's former Hygrade workers.

PORK PACKING has long been a cornerstone of Storm Lake's economy. Its first packer - Storm Lake Packing Company - was established in 1935 as a partnership between Nash Brothers and 
Kingan and Company of Indianapolis, Indiana. Two years later, Kingan bought the plant outright, and it became one of the company's six slaughtering units. Cattle and hogs were the staple of the plant, but sheep were also slaughtered until 1948.

Kingan made a major investment in the plant in 1946-47, expanding its daily slaughter capacity from 500 to 2,100 animals. Facilities were expanded to slaughter and "dress" hogs at a rate of 300 per hour. Cooling facilities and the power plant were also expanded. By the end of the decade, the plant employed about 370 workers. $^{2}$

Hygrade Food Products Corporation bought controlling interest in Kingan and Company in 1952, making Hygrade the nation's fourth-largest meatpacker. Hygrade expanded the plant in October 1973, increasing its capacity by 60 percent. The work force grew to about 650 - slightly more than the number employed when the plant closed in 1981. Virtually all of the Hygrade employees lived in the surrounding community. All were white, and all "line" workers in slaughter and processing were male until the 1970s, when about twelve women took jobs "on the floor."3

Compared to IBP's current standard - with annual turnover between 72 and 96 percent - the Hygrade work force was stable. Former workers attributed the lack of turnover to job security and high wages. Universal membership in Local 191 of the Amalgamated Meat Cutters and Butcher Workmen of North America (AMCBW) and, after 1978, in the United Food and Commercial Workers union (UFCW) reinforced that stability. Indeed, the local enjoyed the cooperation of plant managers, who encouraged new workers to join. ${ }^{4}$

2. Kingan Folks ["A Monthly News Magazine for and about Kingan Employees" published by Kingan \& Co.], (April 1946), 8-9.

3. Carol Johnson, interview, 17 November 1982, Iowa Labor History Oral Project (ILHOP), State Historical Society of Iowa, Iowa City.

4. Gene Moriarty, Steve McCullough, Harlan Hartwig, and Donald Rupp, interviews with author, 10-12 June 1994; Donald Rupp, interview, 17 November 1982, ILHOP. The AMCBW organized the Storm Lake Kingan plant in 1937 shortly after the corporation's flagship plant in Indianapolis signed with the union. See David Brody, The Butcher Workmen: A Study of Unionization (Cambridge, MA, 1964), 190-91. The workers I interviewed all claimed that membership in the unions was universal. The figures on IBP's turnover rate are 
Job security and high wages encouraged many employees to stay on at Hygrade throughout their working lives. Some began in the 1940s and did not retire until the plant closed. Still, few, if any, former Hygrade workers considered meatpacking a "career." One former plant supervisor said, "The money was the lure. As I say, there wasn't a job out there in the plant that anybody would say, 'God, I love this work,' because there is no good, pleasant jobs in the packing plant. But come Friday, when the paychecks came around, [it] made it worthwhile." Due largely to cost-of-living adjustment clauses in their union contracts with Hygrade, base wages in 1981 had risen to $\$ 10.69$ per hour, more than three dollars above the national average for food processing workers. Workers also enjoyed full health insurance benefits and pension plans. ${ }^{5}$

The income potential at Hygrade was not limited to hourly wages. In addition to overtime pay (time-and-a-half for hours over eight in one day) workers also made considerable sums through production incentives. These incentives were available every week for workers, but programs varied by department. Workers on the "boning line," for example, had more opportunities for production incentives than those on the "kill floor." On the boning line incentive pay averaged between $\$ 75$ and $\$ 100$ per week in 1981 . One worker reported making as much as $\$ 205$ in incentive pay in one week, and he averaged $\$ 165$ per week. Production incentives were lower on the kill floor, but still averaged about $\$ 100$ per week. For many workers, incentive bonuses accounted for as much as one-third of their annual gross pay. Average yearly earnings in the plant during the last two years of operation were about $\$ 30,000$. Veteran workers often earned $\$ 35,000$ or more. One worker with more than thirty years in the plant made $\$ 40,000$ during the last year. ${ }^{6}$

from Donald D. Stull, "Cattle Cost Money: Beefpacking's Consequences for Workers and Communities," High Plains Applied Anthropologist 14 (1994), 65.

5. Gene Moriarty, interview with author, 11 June 1994; United States Department of Labor, Bureau of Labor Statistics, Monthly Labor Review 105 (Washington, DC, 1982), 69.

6. Donald Rupp, Steve McCullough, and Lenny McDonald, interviews with author, 10-12 June 1994; Donald Rupp, ILHOP interview; interview and review of pay stubs of a former Hygrade worker who wished to remain anonymous. 
Workers recognized their relatively high pay at Hygrade. They accounted for it by pointing to the plant's high productivity. During the 1970s, "Hygrade put out more tonnage per man than any packing house in the United States," explained a former union official. "In fact, I heard some buyers one time say that we killed about 18 to 20 percent of all the sows in the United States of America. That's one out of five." One former supervisor estimated that the plant processed as much as 27 percent of the nation's sows at peak production of three thousand per day. In addition, the plant regularly processed four thousand butcher hogs per day. ${ }^{7}$

Hygrade workers also enjoyed close working relations with plant managers, and many noted the lack of conflict in the plant. Many employees considered themselves part of a "family."8 The local threatened to strike only once (in 1976), when Hygrade had delayed signing a new contract. But during the weekend preceding the planned Monday walkout, the company signed the contract, and the plant did not lose a single day of production. No wildcat strikes were called in the 44 years of union representation at Hygrade, but the union periodically flexed its muscle by slowing down operations, "to let them know we could do that. ... there's always ways ya know you can slow up production." ${ }^{\prime \prime}$

7. Harlan Hartwig and Gene Moriarty, interviews with author; Donald Rupp, ILHOP interview.

8. Carol Johnson, interview, 11 November 1982, ILHOP. The close relations between the union and plant managers were confirmed in an annual all-male ritual. "The union had a steak supper once a year and invited all the company personnel, government employees [USDA inspectors]. It was a stag affair. It wasn't the wives there. Anybody that worked out there was invited and the union picked up the tab." This event took place annually until the last two years of the plant's operation. Donald Rupp, interview with author; Donald Rupp, ILHOP interview.

9. Donald Rupp, interview with author; Donald Rupp, ILHOP interview; Carol Johnson, ILHOP interview; Tom Robbins, interview, 1 April 1983, ILHOP; Wallace Taylor, interview, 18 November 1982, ILHOP. For discussion of UPWA activism in other plants, see, for example, Wilson J. Warren, "When 'Ottumwa Went to the Dogs': The Erosion of Morrell-Ottumwa's Militant Unionism," Annals of lowa 54 (1995), 217-43. 
STORM LAKE'S HYGRADE PLANT never completely shut down due to labor conflict, but in 1978 the threat of permanent closure initiated the first serious confrontation between labor and management in the plant's history. Ultimately, the company did not carry out its initial threat to close the plant, but it laid the groundwork for labor-management conflict over the following three years.

Citing market conditions and hog supplies, Hygrade announced in May 1978 that the plant would close permanently if Local 191 did not accept contract concessions, including a cut in incentive pay. The union refused, and Hygrade announced its intention to carry through with the planned shutdown. The day before the scheduled close, however, Hygrade reversed its decision, citing an improved outlook for hog supplies and profits. Three years later, Hygrade's vice-president for marketing stated that the company had had every intention of closing the plant in 1978 "until the hog situation turned around so dramatically."10

Although Hygrade remained open in 1978, the nature of the relations between the company and its employees changed. Management's approach to the plant itself anticipated its eventual closure. According to one former Hygrade supervisor,

It was about that time when we began to see a slightly different philosophy on the part of the company. I have always felt that management - top management - milked the local plant. It put nothing back into it. There were repairs that were sorely needed, but were not performed. In order to maintain a good clean environment - safe environment - they tended to ignore (at least that was our opinion) the problems that were becoming prevalent. And it was on a gradual scale, a climbing scale, until the day they closed it. . . It always struck me that they had in mind in 1978, and maybe before that, that they were going to dump this plant. Close it, sell it, or whatever. And, as a result, the morale of the people involved began to deteriorate. It wasn't something you could go to work today and say 'oh boy, things have changed.' It was a gradual thing. And the union membership, they began to feel that the boat was coming to the dock. And as a result, they bowed their back. ${ }^{11}$

10. Storm Lake Pilot-Tribune, 25 February 1981; Storm Lake Register, 28 February 1981.

11. Gene Moriarty, interview with author. 
Hygrade workers were able to fend off contract concessions in 1978, but the company demanded contract concessions again in 1980 . Local 191 proposed the elimination of incentive pay if Hygrade would upgrade the plant and its sewage facilities. Plant management and the local agreed on the compromise, but Hygrade's new parent company - Hanson Industries of New Jersey-refused. ${ }^{12}$

The Hygrade contract with Local 191 required the company to give six-months notice of an intended shutdown. On February 24, 1981, under pressure from Hanson Industries, Hygrade announced that a "permanent shutdown" of the Storm Lake facility would take place on August 24. The announcement noted that "rising energy costs and unfavorable labor rates have combined to cause the facility to be operated at a loss with no relief in view for the foreseeable future." Company officials noted that the plant had been profitable for a time after 1978, but began operating at a loss by 1981 . Rising prices for natural gas and other energy contributed to projections for continued losses, but the company also faced the expense of upgrading its sewage facilities to meet state environmental standards. "Unfavorable labor rates" were the central issue, though. After the announcement on February 24, one company official was quoted as saying that the union was not "willing to surrender the gains it has made over the years for our mutual benefit." Local 191 members met only briefly the day after the announcement and sought no further meetings with the company at that time. ${ }^{13}$

Members of the business community and local government officials began assessing the potential impact of the closure, but

12. Hygrade was not the only meatpacking company to be taken over by big conglomerates that ultimately determined their fate. Swift, Wilson, Armour, and Cudahy were also bought by huge corporations looking for short-term profits. For example, Greyhound, after owning Armour for only a few years, sold the company to ConAgra, which laid off all union workers, closed plants, and reopened some plants with nonunion labor. See Hardy Green, On Strike at Hormel: The Struggle for a Democratic Labor Movement (Philadelphia, 1990), 43. For more on the impact of the "merger mania" in meatpacking, see Warren, "When 'Ottumwa Went to the Dogs,'" 238-39, especially n. 34.

13. Storm Lake Pilot-Tribune, 25 February 1981; Storm Lake Register, 28 February 1981. 
they did not actively encourage negotiations or propose solutions to the plant's sewage problems until May. Instead, initial reactions repeated the theme that "Storm Lake will survive." The mayor, for example, stated that losing Hygrade "is going to hurt. I hate to see Hygrade go. The impact here, well, it would have to be tremendous ... but we're going to come out of this." Business leaders were already looking beyond the plant's closure, but noted that it would have an "immediate psychological effect." The loss of a $\$ 15$ million annual payroll would be felt, "but not immediately." Although some submitted that Hygrade's high wages were the community's primary deterrent to recruiting new industry, the director of the Chamber of Commerce stated that he would not like to see Hygrade close as an "incentive" for new industry to move into Storm Lake. Even those who were most optimistic about the community's ability to survive the plant closure agreed that the facility itself was "too good ... to sit idle." In many ways, business leaders faced a curious dilemma: attract new industry with the Hygrade building after it closed, or advocate that the plant remain open despite the recognition that its workers' high wages were a barrier to economic development. ${ }^{14}$

Initially, the city made efforts to keep the plant open by offering industrial revenue bonds to finance improvement of the plant's infrastructure, including its sewage lagoons. These tax-exempt bonds would have been issued through the city with reduced interest rates: The city would not have been obligated to repay the bonds. This was the first time city officials had initiated such a bonding proposal. Previously, they had expected corporations to initiate the process. ${ }^{15}$

Local Hygrade managers and union officials both showed some initial interest in the initiative. On May 13, 1981, a group calling itself Concerned Citizens for Saving Hygrade placed a full-page advertisement in Storm Lake newspapers praising these efforts and encouraging all sides in the dispute to reach an agreement. The ad read, "IT CAN BE DONE... . We applaud those who took part in the United Effort and suggest that this

14. Storm Lake Register, 28 February 1981.

15. Ibid., 23 May 1981. 
kind of continued cooperation just might convince the owners of Hygrade to reconsider the August 24 plant closing decision." That final point was critical, of course, for regardless of the efforts of local union, plant, and city officials, the final decision rested with the parent Hanson Industries. ${ }^{16}$

The early efforts to keep the plant open did not immediately push union and company officials to the bargaining table. Indeed, it was not until July 1981 - some two months laterthat informal talks got under way. Even then, the company insisted that it had not made a formal offer to the union. Local officers, however, considered the company's demands - formal or not-"unrealistic and unacceptable."17 Although the plant was scheduled to close one month later, no further meetings were scheduled at that time.

As the time drew short, two last-ditch efforts were made to keep the plant open. On August 24, just days before the planned closure, the international office of the UFCW and Local 191 requested a two-month extension to allow time for further negotiations. Hygrade accepted, announcing a new closing date of October 24. It soon became evident, however, that the delay did not indicate the company's eagerness to keep the Storm Lake plant open. Rather, it was a ploy to force union concessions at other plants.

Still, the extension did buy more time for city officials to come up with a way to keep the plant open. In September the Storm Lake City Council voted to assume responsibility for improving Hygrade's sewage treatment lagoons at a cost of $\$ 1.5$ million. The local newspaper quoted a Hygrade spokesman who noted that the company responded to the city's proposal by "expressing our appreciation for the considerable commitment on the part of the city. ... The city showed good faith and we appreciate it." The newspaper report continued, "Whatever the results of the discussions with the union ... the chances are better with than without the city's commitment." ${ }^{18}$

16. Storm Lake Pilot-Tribune, 13 May 1981. The advertisement was sponsored by the manager of the local cable television service.

17. Storm Lake Register, 18 July 1981.

18. Ibid., 3 October 1981. 
Labor rates remained the central issue, however. Particularly "devastating" - a term used by Hygrade officials - were the costof-living adjustments required every six months under the union contract. "Inflation has driven that cost rapidly and it is an expense that many of Hygrade's competitors do not have." Incentive pay was not an issue, they insisted, nor was productivity, as they agreed that Hygrade workers were highly productive. ${ }^{19}$

The success of the negotiations did not, however, hinge solely on the willingness of Storm Lake workers to accept the company's demand for the equivalent of a three-dollar per hour pay cut. Local 191 became, in effect, the lightning rod for $\mathrm{Hy}$ grade's efforts to lower labor rates in all of its plants. At issue was not just the contract between the Storm Lake plant and Local 191, but the master contract between Hygrade and two thousand hourly production workers in the company's other meat processing facilities.

The initial pay cut proposal was made only to Local 191 members to keep the Storm Lake plant open. But on October 14, during a meeting in New York between Hygrade's chairman of the board and Lewie Anderson, chairman of the Packinghouse Division of UFCW, Hygrade proposed expanding this proposal to include the Master Agreement with the UFCW. Keeping the Storm Lake plant open would now require the acceptance of a pay cut not only by Local 191 members, but by Hygrade's other meatpacking plant employees as well. Furthermore, Hygrade demanded these concessions midway through the term of the Master Contract. ${ }^{20}$

Local 191 responded that the latest Hygrade proposal was unacceptable. "Hygrade appears to be using Storm Lake as a wedge to achieve mid-term concessions nationally. The union remains open to discussions that involve real problems concerning the Storm Lake plant. But Hygrade ... mistakenly perceives it can achieve mid-term concessions in all of the plants. ${ }^{21}$

19. Ibid.

20. Ibid., 17 October 1981. Hygrade left open to negotiation whether the equivalent of the three-dollar per hour pay cut it demanded would come from wages, benefits, vacation, or some combination of the three. Hygrade insisted that incentive "bonus" pay was not an issue.

21. Ibid. 
Hygrade workers recall how negotiations with Hygrade changed after the corporation extended its demand for pay cuts to other plants. Until that time, the local was willing to accept pay cuts if some of the savings were used to improve the facility and if the company would guarantee that the plant would remain open. But the new demands placed Local 191 in the position of, in effect, determining the fate of workers in other plants and vice versa.

The pay cuts would have saved Hygrade about $\$ 3$ million annually at the Storm Lake plant, and the company's demand for corresponding pay cuts in other plants would have meant additional savings. ${ }^{22}$ For an average Hygrade production worker, the cuts would have meant an annual loss of $\$ 6,200$, based on a forty-hour work week. The loss of wages and benefits, however, was not the only reason Local 191 members found Hygrade's proposal unacceptable. For many workers, it became a matter of principle. The local rank and file rejected the proposal. Hygrade refused further negotiations.

One week later, the plant closed as scheduled. Management personnel stayed on another week to clean and wrap things up. Then most of them became unemployed as well. After the plant closed, only ten employees - managers and security personnel -remained.

HYGRADE CLAIMED that unacceptably high labor rates led to the closure of its Storm Lake plant. An analysis of the meatpacking industry's wage structure provides evidence, however, that high wages alone do not satisfactorily explain the closure of Iowa's meatpacking plants.

For the meatpacking industry as a whole, average hourly wages rose 114 percent between 1970 and 1980, from $\$ 3.98$ to $\$ 8.50$. But the consumer price index rose about 113 percent during the same period, making real wage earnings virtually constant. At the same time, productivity increased by 48 percent. The retail price of meat also increased rapidly during the $1970 \mathrm{~s}$

22. Ibid. After the Storm Lake plant closed, Hygrade's president admitted that its other plants were profitable and that there were no plans to close them at that time. Ibid., 7 November 1981. 
(more than doubling), so that even though wages per pound of meat increased from 3.5 to 5.1 cents, wages of packinghouse workers as a percentage of the retail price of meat declined substantially, from 5 percent to 3.4 percent. A review of the industry's financial data also indicates that wages and salaries declined during the 1970s as a percentage of gross margin (sales less cost of livestock and other raw materials). Wages, salaries and benefits - including those of management personnelaccounted for 49.3 percent of the gross margin in 1970-72 but 47 percent in 1979-81. When the wages of production workers alone are considered, labor costs as a percentage of value added for the entire industry remained constant. Thus, the authors of an authoritative study of plant closings in Iowa concluded in 1983 , "When plants close following a failure to obtain wage concessions ... it cannot be concluded that wage rates were the principal cause, or even a significant cause, of the closing., ${ }^{23}$

But that was exactly the reason Hygrade gave to the public for closing its Storm Lake plant. If that had been the actual reason, the plant potentially could have been saved if Local 191 had agreed to wage and benefits concessions. Some Hygrade workers claimed that the local was willing to accept lower wages, but the last proposal from Hygrade - that cuts had to be accepted by workers in its other plants-left members with no choice. As subsequent events suggest, even when workers accepted lower wages, many plants closed anyway. ${ }^{24}$

The net result of the process throughout the industry was lower wages and, in many cases, the destruction of union representation. There were enough plant closings that unions had to take company demands for wage concessions seriously. Some locals chose to strike rather than accept lower wages. But in most cases, companies simply hired replacement workers and reopened plants with nonunion labor.

AFTER THE HYGRADE PLANT CLOSED, Storm Lake actively sought new owners for the facility. The following April IBP, Inc., purchased the plant for $\$ 2.5$ million, a "modest" trans-

23. Lauria and Fisher, Plant Closings, 52-53, 61.

24. Ibid., 61. 
action that "signaled the start of another revolution in the meatpacking industry. ${ }^{\prime 25}$ Many former Hygrade workers pinned their hopes for future employment on the arrival of the new owner.

When IBP opened its Storm Lake plant in September 1982, starting wages were only six dollars per hour. Average yearly earnings were about half of those paid to Hygrade workers, no production incentives were available, and workers were not guaranteed forty-hour work weeks. In addition, health insurance was not available until after six months on the job. ${ }^{26}$

Still, former Hygrade workers estimate that 200 to 350 of their counterparts applied for jobs at IBP, even though they recognized that their incomes would be much lower than they had been at Hygrade. Motivations varied. Some applied simply to continue qualifying for unemployment benefits. For others, it was the only type of work they had ever known. Many were willing to accept the lower wages offered by IBP to keep their homes and families in Storm Lake. Many former Hygrade workers felt that their extensive experience as meatpackers would make them attractive to IBP. But that was not the case. "They said they were hiring local people," said one former Hygrade worker, "but they didn't designate any Hygrade people. They made the statement that most of the Hygrade people left the area, which is not true." Another worker said, "They didn't even want to talk to me. They wouldn't even answer my questions. And I said, 'hey, I've got 16, 17 years of packing house work.

25. T. W. Lippman, "Iowa Beef Makes its Move on an Anxious Pork Industry," Washington Post, 18 April 1982. IBP, Inc., was formerly lowa Beef Processors, Inc. The company shortened its name after 1982 to reflect its decision to expand beyond just beef processing. IBP president Robert Peterson acknowledged that the Storm Lake purchase was "the first stage of a planned major expansion . . . into the pork business." Ibid. For accounts of IBP's development, see International Directory of Company Histories, s.v. "IBP, Inc." (Chicago, 1990), 2:515-17; Dale C. Tintsman and Robert L. Peterson, Iowa Beef Processors, Inc.: An Entire Industry Revolutionized! [published address to the 1980 Nebraska Dinner of the Newcomen Society of North America, 9 October 1980], (New York, 1981); and Wayne Swanson and George Schultz, "The General Motors of the Meat Industry," in Prime Rip, ed. Wayne Swanson and George Schultz (Englewood Cliffs, NJ, 177-207).

26. Mark A. Grey, "Pork, Poultry, and Newcomers in Storm Lake, Iowa," in Donald D. Stull, Michael J. Broadway, and David Griffith, eds., Any Way You Cut It: Meat Processing and Small-Town America (Lawrence, KS, 1995). 
I'm working at [another meatplant]. Why can't I do the same thing in Storm Lake that I'm drivin' a hundred miles a day to?' They didn't even want to talk to me." ${ }^{27}$

Of the hundreds of former Hygrade workers who applied at IBP, fewer than thirty were hired, despite their experience and local availability. ${ }^{28}$ One worker recalled,

they brought this [IBP President] Peterson in here and they had the red carpet out for him up at the city hall and all that fakey stuff. Somebody from the crowd asked, "Are you gonna hire Hygrade workers?" His answer was "Yes, but we'll run the plant." Which is fine. But he lied. Most of us went out there and applied. Very few of us ever got called. I was one that thought he was gonna get hired, and they brought me and interviewed me... . Said they'd let me know the following Tuesday when I was to start. That's been twelve years and they haven't called yet! ${ }^{29}$

Why were so few hired? Some Hygrade workers cited their high wage expectations as a possible explanation, but that does not account for those hundreds of workers who applied for IBP jobs fully aware of lower wages. The more plausible explanation-and the one cited by the majority of Hygrade workers I interviewed - suggests that IBP wanted to keep workers with extensive union backgrounds out of the plant. That may have represented a correct calculation on the management's part. One worker admitted that former Local 191 members sought to organize the new plant. One man hired by IBP was fired within months ostensibly for insubordination, but actuallyaccording to the worker-because he initiated efforts to organize plant workers. ${ }^{30}$

WITHOUT HIRING former Hygrade workers, IBP filled its labor rolls with others from the region. Soon, however, a growing work force and high turnover and injury rates forced

27. Donald Rupp, interview with author; former Hygrade workers interviewed by author who wished to remain anonymous.

28. An exact number of former Hygrade workers hired by IBP is unavailable; I have used an estimate by former Hygrade workers I interviewed.

29. Anonymous interview with author.

30. Anonymous interviews with author. 
the plant to look elsewhere. In many cases, new workers arrived from out of state. Most of the new workers were minorities, immigrants, or refugees. By 1992, IBP employed 1,200 workers, one-third of whom were immigrants or refugees from Laos or Mexico. $^{31}$

As IBP imported workers from outside of Storm Lake - and Iowa - many Hygrade workers felt displaced by the newcomers. One recalled, "The rumor in the beginning was they were gonna hire everybody back so there would be a lot of job experience. They'd give back the Storm Lake people their jobs. Then we started seeing cars from Texas and Illinois, I mean everywhere." When "IBP started pulling in these people from here, there, and everywhere, sure the rank and file felt they were being replaced by those who didn't belong here, taking their jobs. ${ }^{\prime 32}$

In one concluding irony, IBP officials confirmed in September 1982 that the president and business agent of Local 191 had taken a management position at the Storm Lake plant. He had been the local's president since 1975 and became business representative in January 1982, after the Hygrade plant closed. That same month a Local 191 vice-president resigned from the union to join IBP. Storm Lake's UFCW International Representative speculated that IBP might have been attempting to curtail union organizing attempts at the new plant by hiring the local's chief officers. IBP denied this contention, of course, stating that the men were hired "because we thought they would make good supervisory personnel. That's why we hired them. Period." ${ }^{\prime 33}$

IN MANY WAYS, the closure of the Hygrade plant in Storm Lake, and its eventual reopening by IBP, illustrates the dramatic changes in the meatpacking industry in the late 1970s and early 1980s. When the Hygrade plant shut down and was reopened by IBP a year later, few Storm Lake residents and former $\mathrm{Hy}-$ grade workers understood the significance of that transformation. One former worker who believed he did recognize its

31. Grey, "Pork, Poultry, and Newcomers."

32. Anonymous interviews with author.

33. Storm Lake Register, 4 September 1982, 2 October 1982. 
importance said, "Knowing what [IBP] had done in the beef industry, I had a gut feeling that if they went into pork, they would turn it upside down just as they did the beef industry. And they did!" ${ }^{\prime 34}$ In less than ten years, the Storm Lake plant became the world's second-largest pork operation, with a daily slaughter capacity of 13,400 (or 3.35 million hogs per year). IBP now operates five pork plants in Iowa and one in Nebraska, with a combined daily capacity of 60,800 hogs -16 percent of the national capacity. ${ }^{35}$

Storm Lake is significant in the history of Iowa's pork industry because it was where IBP launched its campaign to become the world's largest producer of pork. But it is also significant because former Hygrade workers - regardless of whether they understood their role in that transformation at the time-played a pivotal role in the plant's closure, despite their negotiations (and a willingness to accept concessions) to save their jobs. These "old line" meatpacking workers were the ones most deeply affected by the changes in the industry.

34. Gene Moriarty, interview with author.

35. Center for Rural Affairs, Center for Rural Affairs Special Report: Corporate Farming Update! Spotlight on Pork (Walthill, NE, 1994), 10. 
Copyright of Annals of Iowa is the property of State of Iowa, by \& through the State Historical Society of Iowa and its content may not be copied or emailed to multiple sites or posted to a listserv without the copyright holder's express written permission. However, users may print, download, or email articles for individual use. 